\title{
Verdunde Tolkien vir die kinders
}

\begin{tabular}{|c|c|}
\hline $\begin{array}{l}\text { Book Title: } \\
\text { Die heerser v } \\
\text { Die koning ke }\end{array}$ & $\begin{array}{l}\text { In die ringe: } \\
\text { er terug }\end{array}$ \\
\hline Book Cover: & \\
\hline $\begin{array}{l}\text { DIE KON } \\
\text { KEER TE }\end{array}$ & \\
\hline $\begin{array}{c}\text { J.R.R. TOL } \\
\text { DIF HERSERR VAN } \\
\text { DERE } 3\end{array}$ & $\begin{array}{l}\text { KIEN } \\
\text { F RINGE }\end{array}$ \\
\hline $\begin{array}{l}\text { Author: } \\
\text { Tolkien, J.R.R. } \\
\text { Geldenhuys) }\end{array}$ & (vertl. Kobus \\
\hline $\begin{array}{l}\text { ISBN: } \\
978-1-4853-0\end{array}$ & $977-2$ \\
\hline $\begin{array}{l}\text { Publisher: } \\
\text { Protea Boekh } \\
\text { R285.00* } \\
\text { *Book price a }\end{array}$ & $\begin{array}{l}\text { uis, } 2020 \text {, } \\
\text { time of review }\end{array}$ \\
\hline $\begin{array}{l}\text { Review Title: } \\
\text { Verdunde Tol } \\
\text { kinders }\end{array}$ & ien vir die \\
\hline $\begin{array}{l}\text { Reviewer: } \\
\text { Mariëtte van }\end{array}$ & $\operatorname{Graan}^{1} \oplus$ \\
\hline $\begin{array}{l}\text { Affiliation: } \\
{ }^{1} \text { Department } \\
\text { and Theory o } \\
\text { University of } \\
\text { Pretoria, Sout }\end{array}$ & $\begin{array}{l}\text { ff Afrikaans } \\
\text { Literature, } \\
\text { outh Africa, } \\
\text { h Africa }\end{array}$ \\
\hline $\begin{array}{l}\text { Correspondin } \\
\text { Mariëtte van } \\
\text { vgraam@unis }\end{array}$ & $\begin{array}{l}\text { g author: } \\
\text { Sraan, } \\
\text { a.ac.za }\end{array}$ \\
\hline $\begin{array}{l}\text { How to cite th } \\
\text { Graan, M.V., } \\
\text { Tolkien vir die } \\
\text { Literator } 41 \text { (1 } \\
\text { https://doi.or } \\
\text { v41i1.1742 }\end{array}$ & $\begin{array}{l}\text { is book review: } \\
020, \text { 'Verdunde } \\
\text { kinders', } \\
\text {, a1742. } \\
\text { /10.4102/lit. }\end{array}$ \\
\hline Read online: & \\
\hline 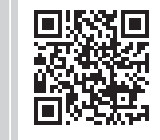 & $\begin{array}{l}\text { Scan this QR } \\
\text { code with your } \\
\text { smart phone or } \\
\text { mobile device } \\
\text { to read online. }\end{array}$ \\
\hline
\end{tabular}

Die bakens van Gondor brand. Pippin en Gandalf haas hulle na Minas Tirith. Theoden en Éomer kry die Rohirrim gereed om Gondor te hulp te snel, met Merrie wat strydgereed saamgaan en Éowyn wat noodgedwonge in die geheim opmars. Aragorn, Legolas, en Gimli neem die Paaie van die Dooies. Die Nazgûl en al Sauron se magte sak vanuit Mordor toe op Middelaarde, terwyl Frodo, Sam en Gollum al nader aan die Berg van Verdoemenis kruip om die Een Ring te vernietig ... Die gort is behoorlik gaar in Die Koning Keer Terug, die vertaling van The Return of the King en die laaste boek van J.R.R. Tolkien se epiese en ikoniese The Lord of the Rings-trilogie (LOTR).

Kobus Geldenhuys is 'n ervare en bekroonde vertaler van jeugliteratuur, en het met die laaste twee boeke in die LOTR-trilogie die vertaalwerk by Janie Oosthuysen oorgeneem. Sy het The Fellowship of the Ring en die voorafgaande, The Hobbit, behartig. ${ }^{1}$ In hierdie resensie word gefokus op die vertaalwerk in Die koning keer terug, en die bronteks word dus met die vertaling vergelyk eerder as selfstandig gelees.

Uit 'n direkte vergelyking blyk etlike foute. Reeds op die eerste bladsy is 'n volledige sin, 'So the night wat not yet old and for hours the dark journey would go on', uit die vertaling weggelaat (bl. 11); op die volgende bladsy ontbreek 'War is kindled' (bl. 12). Emyn Arnen word met Emyn Muil verwar (bl. 15), 'nine summers' word 'sewe somers' (bl. 32), en die Groot Rivier, 'bending in a mighty sweep south and west again' (bl. 27), loop nou 'suid en dan weer noord' (bl. 32). 'The men of Ringló Vale [...] striding on foot' (bl. 36-37) marsjeer onverklaarbaar 'kaalvoet' (bl. 42). Rentmeester Denethor word sommer 'koning' (bl. 149). Éomer en Éowyn se name word herhaaldelik omgeruil (bl. 156). Die dreigement van 'n ork, 'I'll give your name and number to the Nazgûl' (bl. 239), word 'Ek sal vir jou die Nazgûl se naam en nommer gee' (bl. 242).

Sulke detail sal nie ongesiens by 'n LOTR-aanhanger of 'n aandagtige leser verbygaan nie.

Daar is ook ander kwelpunte in die vertaalwerk, insluitende ongewone woordkeuses. Daar is naamveranderinge soos Merry wat Mannetjies heet in Oosthuysen se vertaling, maar Merrie in Geldenhuys s'n, of adelaars vir die groot Eagles (bl. 91), wat Oosthuysen as die Arende behou het; ${ }^{2}$ ook die effektiwiteit of noodsaak van die verwerking van lengte-eenhede van leagues na myle en fathoms na voete; die verkleining van hoofletters wat beskrywings van eiename maak (Fell Riders/wrede ruiters), en ander verskille tussen Geldenhuys en Oosthuysen se vertalings. Al hierdie kwessies kan nie in een resensie gedek word nie, en hier is heelwat vir navorsers in die vertaalkunde om te ondersoek.

Verder is daar helaas ook Afrikaanse taalprobleme in die boek, soos die herhaaldelike gebruik van 'ten slotte', waar 'uiteindelik' of 'oplaas' meer korrek sou wees ('En so kom hulle ten slotte by die privaatvertrek van die heer van die stad' - p. 93). Daar is ook Engelse woorde soos sire (bl. 101) en tik-/spelfoute soos 'sy hy' ('sê hy'; p. 215), 'hule' (bl. 216) en 'sryf' (bl. 282). In minstens een geval word 'n teksgedeelte in twee variasies herhaal:

Hierop sit Gandalf orent en gryp die armleunings van sy stoel, maar hy sê niks nie, en met 'n blik keer hy die uitroep op Pippin se lippe. Toe kyk Gandalf skielik op en gryp die armleunings van sy stoel, maar hy sê niks nie, en met 'n blik keer hy die uitroep op Pippin se lippe. (bl. 94).

Sulke foute moes nie by die vertaler óf die taalversorger verbygeglip het nie.

\footnotetext{
1.Ek het Oosthuysen se vertalings Die Hobbit en Die heerser van die Ringe: Die kameraadskap van die Ring geresenseer vir Literator Alhoewel Geldenhuys reeds met Die Twee Torings oorgeneem het, word laasgenoemde nie in hierdie resensie betrek nie, omdat ek dit nie onder oë gehad het nie.
}

2.Geldenhuys se teks verdien wel'n pluimpie vir die meer eweredige benadering tot die behoud van eiename uit die bronteks. 
Laastens is die sinopsis aan die begin én alle bylaes ${ }^{3}$ aan die einde van die boek uitgelaat. Gesamentlik skep hierdie probleme die indruk dat hierdie boek afgejaag is en dít sal nie deug as jy met Tolkien werk nie.

Beide Geldenhuys en Oosthuysen verdien erkenning en lof vir die opneem van die enorme taak om Tolkien in Afrikaans te vertaal, en dit is nie my bedoeling om hierdie groot werk af te maak nie. Die toevoeging van LOTR - nou seker Heerser van die Ringe (HVDR) - tot die Afrikaanse boekeskat is geensins gering nie. My kernbeswaar teen al vier LOTR-vertalings bly egter dat die Afrikaanse tekste net slaag as dit onkrities en nie vergelykend met die Engelse tekste gelees word nie. Buiten die kompleksiteite rondom die taal van fantasie in Afrikaans, ly beide Oosthuysen en Geldenhuys se vertalings onder ' $n$ besluit wat vroeg deur die uitgewerspan geneem is: die doelbewuste vereenvoudiging van die teks met die oog op die jeugprosamark.

The Hobbit was wel op jeugdige lesers gemik, maar met LOTR het Tolkien beslis nie net vir jonges geskryf nie. LOTR word wyd beskou as oorgangsliteratuur (literatuur wat nie tot die jeug- óf volwasse lesersgroep beperk word nie), en heelwat Engelse lesers het LOTR in hul tienerjare of vroeë 20 's verslind. Lank voor die ikoniese LOTR-films het jonges wêreldwyd onverdunde Tolkien gelees: die komplekse

3.Annals of the Kings and Rulers, The Tale of Years (Chronology of the Westlands), Family Trees (Hobbits), Calendars, Writing and Spelling (alles wat jy sou wou wee oor die tale van Middelaarde). towerkrag van sy taal (en tale) en diggeweefde verhaal is aan jeugdige lesers gebied presies soos dit aan volwasse lesers gebied is. Dit was nie Lord of the Rings for Kids nie.

Wat het die Afrikaanse jeug dan gesondig om verdunde Tolkien te verdien? Was die veronderstelling dat hierdie fantasie (of minstens die bylaes in die boek) te moeilik sou wees vir jonger Afrikaanse lesers? Wat dan van die ouer lesers wat fantasie in Afrikaans wil lees? Daar is tog nie 'n groot tekort aan fantasie (insluitende vertaalde werke) in die jeugboekmark nie - beide Geldenhuys en Oosthuysen het hier reeds groot bydraes gelewer. ${ }^{4}$ Die groter leemte is in die boekmark vir ouer jeugdige en volwasse Afrikaanse lesers. Uitgewers begin reeds die kans waag om meer nismarkboeke te publiseer vir die volwasse leser wat miskien nie op soek is na 'n krimi, romanza of hogere literatuur nie, en HVDR is ook 'n stap in hierdie rigting.

Die Afrikaanse HVDR-trilogie is egter nie ' $n$ volbloed-Tolkien nie, en die onnodige verdunning voel soos 'n tipe oogrol in die rigting van volwasse fantasielesers ('Fantasie is vir kinders, nie vir grootmense nie'), én 'n onderskatting van die jonger lesers ('Tolkien is te moeilik vir jou'). Myns insiens kon hierdie vertalings in die geheel met meer agting vir die bronteks en LOTR-aanhangers behartig word. Tolkien én Afrikaanse fantasielesers van alle ouderdomme verdien beter.

4.Beide Oosthuysen en Geldenhuys het boeke uit J.K. Rowling se Harry Potter-reeks in Afrikaans vertaal. Geldenhuys se repertoire van jeugboek-vertalings sluit ook die volgende in: The lion, the witch and the wardrobe (C.S. Lewis), How to tame your dragon (Cressida Cowell); en Charlie and the chocolate factory (Roald Dahl). 